\title{
DIMERIZATION OF ECODAM-METHYLASE INDUCED BY THE OLIGONUCLEOTIDE SUBSTRATE
}

N. I. Rechkunova, V. V. Zinoviev, E. G. Malygin, Yu. A. Gorbunor, S. G. Popov, V.F. Nesterenko, Ya. I. Buriyanov

All-Union Research Institute of Molecular Biology, Koltsovo, Novosibirsk Region Institute of Biochemistry and Physiology of Microorganisms,

Academy of Sciences of the USSR, Pushchino, Moscow Region

$\mathrm{Sum}$ m a r y

The Ecodam-methylase has been investigated for its interaction with the 20-base oligo. nucleotide duplex containing the enzyme recognition site. An increase of the enzyme molecular weight was detected by the gel-filtration and sucrose densily gradient contrifugation methods. The maximal value of the molecular compicx weight was observed when concentrations of the enzyme and the substrate were equal. The results obtained prove the formation of the dimeric enzyme form in the substrate presence.

1. Действие ДНК-метилазы Ecodam на однонитчатые послсдоватс.тьности и сннтетинеские олнгонуклсотнды / В. В. Знновьев, Ю. А. Горбунов, С. І. Попов и др. // Молекуляр. биология.-1985-19, 수 4.- С. $947-953$.

2. Herman G. E., Modrich P. Escherichia coli dam methylase. Physical and catalylic properties of the homogeneous enzyme // J. Biol. Chem.-1982.-257, N 5.- P. 26052612.

3. Brooks J. E., Blumenthal E. M., Gingeras T. R. The isolation and characterization of the Escherichia coli DNA adenine methylase (dam)gene//Nucl. Acids Res.- 1983.11, N 3.- P. $837-851$.

4. Нсследование стсхиометрии комплексов при взаимодействии Ecodam-метилазы с субстратами методом малоугиового рентгеновского рассеяния / В. В. Знновьев, Ф. В. Тузиков, Э. Г. Малыгин и др.// Конформационные изменения бнополимеров в раствоpax: Материалы VI снмноз. (Тбнлисн, 20-22 ноября 1985 г.).-Тбн.писи, 1985. C. 56 .

5. Бурьянов Я. Н., Захариенко В. Н., Баев А. А. Выделение, очистка и некоторые свойства адениновой ДНК-метнлазы Ecodam // Док.т. АН СССР.-1981.-259, № 6.C. $1492-1495$.

6. Hirose T., Grea R., Itakura K. Rapid synthesis of trideoxyribonucleotide blocks // Tet. rahedron Lett. - 1978. - N 28.- P. 2449-2452.

7. Martin R. G. Ames B. N. A method for determining the sedimentation behavior of clzymes: application to protein mixtures // J. Biol. Chem.-1961--236, N 5.-P. 1372-1379 .

8. Siegel L. M., Monty K. G. Determination of molecular weights and fractional ratios of proteins in impure systems by use of gel filtration and density gradient centrifugaíon // Biochim. et biophys. acta.-1966.-112, N 2.- P. 346-362.

ВНИИ молекупяр, биологин, Кольцово Новоснб. обл. Ин-т биохнмни и фнзнологин мнкроопганизмов АН СССР.

По.тучсно 10.09 .86 Пущино Москов. об.

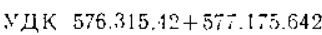

\section{ИЗМЕНЕНИЕ УРОВНЯ АДФ-РНБОЗИЛИРОВАНИЯ В ХРОМАТИНЕ МОЗГА КРОЛИКА ПРИ ДЕЙСТВИИ ЭСТРАДИОЛА}

\author{
Г. А. Паносян, Э. Г. Саркиеян, Э. С. Геворкян, Л. В. Карабашян
}

Нзвестно, что ряд внутрнядерных процессов зависит от степени АДФ-рнбозн.тировашия ядерных белков [1-3]. Несмотря на возрастающий интерсс исследоватслей к этой посттрансляцнонной модификации бслков, се роль в псуиествлснии основных функциї ядра остастся неясной. Идентифнкация АДФ-рибознлированных белков, определенне уровня их модификации шрн раз.личных функциона.льых состояниях к.летки яв.лястся иеобходимым для понимания физнологического знатения этого пропесса. Нзменснис степени $А Ц Ф$-рнбозилирования ядерных белков может сказатьея па суперструктуре хроматина и привести к измененпо уровня его транскрибнруемості. В зтом аспекте возможная взанмосвязь между уровнем $\Lambda$ Д-рибозилирования бетков хроматниа ш процсссом гормональной активации генома представлястся весьма всроятиой. 
Хорошо известно, что стероидные гормолы, в частпости эстрогены, способны индуцировать биосинтетические процессы в тканях-мишенях, в том числс в клетках головного мозга $[4,5]$.

В настоящем сообщении приводятся данные о стимулированом эстрадиолом изменснии активности (АДФ-рибоза)полимеразы (КФ 2.4.2.30) хроматина клеток головного мозга кролика.

В экспсрименте использовали 1,5-месячных самок кроликов. Контрольным животным вводили пропиленгликоль, опытным кро.тикам инъецировали эстрадио.т-17 B («Sigma», CША) в пропилснгииколе в концситрацин 10 мкг на 100 г массы животного. $\Lambda$ ктиномицин Д вводили в концентрацин 100 мкг на 1 кг массы животного за 1 ч до введения гормона. Хроматин из цельного мозга кроликов выделяли по истоду, описанному В [6]. УФ-спектр хроматина снималю в $3 \mathrm{M}$ растворе $\mathrm{NaCl}$ на спектрофотометре Specord UVVIS (ГДР). Koнпентрации белка и ДНК определяли по [7]. Уровень АДФ-рибозилирования бслков хроматина определяли в его тотальной фракции по [8]. Реакционная смесь объемом 0,25 мт содержала 100 мM трис- $\mathrm{HCl}, \mathrm{pH} 8,0$, $10 \mathrm{MM} \mathrm{MgCl}_{2}, 1$ мM дитиотренто.т, хроматин мозга (200 мкг по белку) и 0,02 мМ ${ }^{14} \mathrm{C}$-НАД с удстьной радиоактниностью 9,6 ГБк/нмоль («Амегsham», Англия). Реакцию проводили в течение 5 мин при $25^{\circ} \mathrm{C}$ и останавливали добавлегием 1 мл холодной $20 \%$-ной ТХУ, одновременно перенося пробы в лед. Белки осаждали на иитроцеллюлозных фильтрах («Sупpor», ЧССР). Фильтры промывали 3 м. 10 мМ НАД, затем $20 \%$ - и

Уровень АДФ-рибозилирования в хроматине ноза а неполовозрельх крольчих через разное время после введения эстрадиола

The level of $A D P$-ribosylation in the chromatin of inmature female rabbit brain during the various periods of estradiol action

\begin{tabular}{|c|c|c|}
\hline \multirow[b]{2}{*}{ Обработка животных, ч } & \multicolumn{2}{|c|}{$\begin{array}{l}\text { Уровснь А ДФ-рибозилиро. } \\
\text { вания в хроматнне мозга, }\end{array}$} \\
\hline & $\begin{array}{c}\text { нмоль } А Д Ф-р и б о-~ \\
\text { зы.мг белка } \\
\times \text { мин }^{-1}\end{array}$ & $\because$ \\
\hline \multirow{6}{*}{$\begin{array}{l}\text { Контроль } \\
\text { Эстрадиол, } 1 \\
\text { Эстрадиол, } 4 \\
\text { Актиномицин Д, } 1+ \\
\text { +эстрадиол, } 4 \\
\text { Эстрадиол, } 24 \\
\text { Актиномицин Д, } 1\end{array}$} & 0,2204 & 100 \\
\hline & $0,2714 \pm 0,02 *$ & 123 \\
\hline & $0,6624 \pm 0,05$ & 300 \\
\hline & $0,1224+0$, & 50 \\
\hline & $0,1280 \pm 0,02$ & 58 \\
\hline & $0,1236 \pm 0,01$ & 56 \\
\hline
\end{tabular}

* $P<0,1$; остальные $-P>0,05$.

$5 \%$-ной ТХУ соотвстственио. Фильтры высушивали, измеряли радиоактивность в толуоловом сцинтилльторе на счетчике SL-4221 (Франция). За активность фсрмента -(АДФ-рибоза) полимеразы было принято количество НАД, включсниого в кислотонерастворимую фракцию, в пересчете на 1 мг бслка в 1 мин.

О наличии активности (АДФ-рибоза) полимеразы в клетках головного мозга в литературе имсются единичные данные $[9,10]$. Мы проводили изучение измснсния уровня АЛФ-рибознирования тотального хроматина в отличие от исследований в работах $[10,12-15]$, гдс посттрансляционную модификацию изучали или в ядсрных экстрактах, или в выделенных белках хроматина.

Қак видно из приведснных в таблицс данных, ввсденис эстрадио.та животным приводнт к измснснию уровня АДФ-рибозилирования бслков ужс на начальных этапах дсйствия гормона. Так, чсрез 1 ч наб.людается повышенис уровня АДФ-рибозинировання лочти на $25 \%$. В дальнейшем, к 4-му часу действия гормона, когда уровень стерондной активации биосинтетичсских процессов доходит гюочти до максимума [11]. наблюдается 3-кратное повышенис уровня $\Lambda Д Ф$-рнбозилирования бстков. Эти результаты свидетельствуют о корреляцин процессов гормональной активации генома и данной посттрансляционной модификация белков хроматина. Ко времени же поннжения скорости бносинтстичсских процессов (к 24-му часу после введения гормона) уровсиь АДФ-рибозилирования бслков хроматина снижастся на $45 \%$ пижс уровня контроля. Получепные результаты согласуются с литературнымн данными, указывающими на снижснис уровня (АДФ-рибоза)полимеразы, вызванного разными гормонами в ядрах различных ткансй чсрез 24 ч послс ввсдсния гормона [12-15]. Интерссно, пто гиккокортикоиды такжс уменьшают уровень АДФ-рибозилирования, причсм тех негшстоновых белков хроматнна, которые ответственны за регуляпию генетитеской актпвности [15]. Для подтверждения корреляции между активацией генома чсрез 4 ч после введения гормона и АДФ-рибозилированілем бслков нами бы.и поставлены эксперимснты с актиномицином Д, которые показали, что увеличение уровня АДФ-рибознтирования бслков полностью снимается введсиисм этого ингибитора. Это позволяет рассматривать, эффскт, вызванный эстрадиолом, наряду с другими возможностями как индукцио фермснта (АДФ-рибоза)полимсразы. В доступной нам литературе не оказалось 
данных по исследованию гормональной чувствительности процесса АДФ-рибозилирования белков хроматина в тканях головного мозга. Нам впервые удалось показать, что эта посттрансляционная модификация белков хроматина мозговой ткани стимулируется эстрадиолом. Четких данных о механизме влияния гормона на этот процесс нет. Полученные нами результаты наряду с литературными [1] свидетельствуют о возможной регуляторной роли процесса АДФ-рибозилирования белков хроматина в гормональной активации генетического алларата у эукариот, в частности в тканях головного мозга.

\section{CHANGES OF ADP-RIBOSYLATION LEVEL IN RABBIT BRAIN CHROMATIN UNDER THE ESTRADIOL ACTION}

\section{G. A. Panosyan, E. G. Sarkisyan, E. S. Gevorkyan, L. V. Karabashyan}

Institute of Experimental Biology,

Academy of Sciences of the Armenian SSR, Yerevan;

State Universily, Yerevan

\section{Sum a r y}

The action of estradiol on AD.P-ril osylation level in the brain chromatin of preadolescent rabbits in various periods after he mone injection has been studied. The level of ADP-ribosylation is shown to increase during the activation of biosynthetic processes and to decrease with the lowering of the rate of these processes. The results obtained point to the possible regulatory role of ADP-ribosylation process in the hormonal activation of genetic apparatus in eucaryotes, in particular in the brain tissue.

1. Бараt/coв $\Gamma$. Д. Участие поли(АДФ-рибозы) в генетичсских процессах //Успехи совр. генетики.- 1985-- № 13.- С. 136-172.

2. Gaal J. C., Pearson C. K. Eucaryotic nuclear ADP-ribosylation reactions // Biochem. J. $1985-230, \mathrm{~N}$ 1.-P. $1-18$

3. Ueda K., Hayaishi O. ADP-ribosylation//Ann. Rev. Biochem.-1985.-54.-P. 73100 .

4. Паносян Г. А., Геворкян Э. С., Саркисян Э. Г. Индукция холинэстеразы эстрадиолом // Физиология и биохимия медиаторных процессов: Тез. III Всесоюз. конф.Москва, 1980 - С. 152 .

5. Moudgit $V$. K., Kanungo M. S. Induction of acetylcholinesterase by $17-\beta$ estradiol in the brain of rats of various ages // Biochem. and Biophys. Res. Communs. - 1973.52, N 3. P. $725-730$

6. Graziano S. Z., Huang R. Ch. C. Chromatographic separation of chick brain chroma. tin proteins using a SP-sephadex column// Biochemistry.-1971.-10, N 25.P. $4770-4777$.

7. Layne E. Spectrophotometric and turbidimstric methods//Meth. Enzymol-- 1957.3.- P. $450-455$.

8. Ito S., Shizuta Yu., Hayaishi O. Purification and characterization of poly(ADP-ribose) synthetase from calf thymus // J. Biol. Chem.-1979. -254, N 9.-P. 3647-3651.

9. Das B. R., Kanunco M. S. ADP-ribosylation induced changes in the conformation of the brait of developing rats // Biochem. Int.-1986.-12, N 2.- P. 303--311

10. Gill $D$. M. Poly (adenosine diphosphate ribose) synthesis in soluble extracts of animal organs // J. Biol. Chem.-1972.-247, N 18.-P. 5964-5971.

11. Estrogen and antiestrogen action in reproductive tissues and fumors/B. S. Katzenellenbogen, H. S. Bhakoo, E. R. Ferguson et al. // Rec. Progr. Horm. Res.-1979.35.- P. $259-300$.

12. Jackozecki G., Kun $E$. The influence of triiodothyronine on polyadenosine-diphosphoribose polymerase and RNA synthesis in cardiocyte nuclei // Mol. and Cell. Cardiol.1982.- Supp1. 14, N 3.- P. 65-70.

13. Glucocorticoid-induced reduction of poly(ADP-ribose) synthetase in nuclei from chick embryo liver/A. Kitamura, Yo. Tanigawa, T. Yamamoto et al.//Biochem. and Biophys. Res. Communs. - 1979.-87, N 3.- P. 725-733.

14. The effects of thyroid hormone on in vitro phosphorylation, acetylation, and ADP. ribosylation of rat liver nuclear proteins / V. M. Nikodem, D. R. IJuang, B. L. Trus, J. E. Rall // Hormone and Metab. Res.-1983.-15. N 11.-P. 550-554.

15. Tanuma S.-I., Johnson L. D., Johnson G. S. ADP-ribosylation of chromosomal proteins and mouse mammary tumor virus gene expression //J. Biol. Chem.--- 1983.258, N 24.-P. $15371-15375$.

Ин-т эксперим. бнологии АН АрмССР, Ереван

Получено 08.10 .86

Ереван. гос. ун-т 